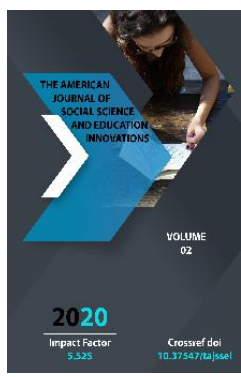

\title{
The Issues Of Tax Liabilities Accounting
}

\author{
Tuychiev Alisher Jurayevich \\ Professor, Doctor of Economics, Vice-rector of Tashkent Institute of Finance, Uzbekistan \\ Khotamov Komil Rabbimovich \\ Professor of Tashkent Institute of Finance, Doctor of Economics, Uzbekistan
}

\begin{abstract}
Journal Website:
http://usajournalshub.c

om/index,php/tajssei

Copyright: Original

content from this work

may be used under the

terms of the creative

commons attributes

4.0 licence.
\end{abstract}

\section{ABSTRACT}

This article is devoted to the consideration of theoretical and methodological views, practical and legal basis for the accounting of liabilities, including tax liabilities. In addition, the article studies the current state of tax liability accounting and provides relevant proposals and recommendations.

\section{KEYWORDS}

Liability, tax liability, tax liability accounting, accounts for tax liability.

\section{INTRODUCTION}

In accounting, tax liabilities are calculated in reliance upon the tax base and rates and paid in accordance with the tax period. Tax reports are compiled and then these tax reports are submitted to the tax authorities. This process is implemented directly by the economic entity. Therefore, it is compulsory for taxpayers to determine the tax base, calculate and pay taxes, reflect them in the reports and provide information to the tax authorities according to the established procedure. Thus, it is required for economic entities to keep records of tax liabilities.

\section{LITERATURE REVIEW}

The opinion of the Professor B. Isroilov about the accounting of tax liabilities and its urgency is "This means that taxes calculated by legal entities and their transfer to the budget, expenses incurred, accurate and correct accounting of taxes in accounting are not only the responsibility of taxpayers, but also raise their interest. In addition, the relationship between economic entities and the state is analyzed on the basis of accounting data, and the prospects for the implementation of reforms are determined as well. Therefore, the accurate organization and maintenance of tax accounting ensures that the enterprise avoids the payment of large fines, and the government receives the established revenues in due time" (Isroilov, 2006).

Therefore, it is essential to set up a tax liability accounting. This is because the 
business process and operations that occur with the help of accounting are monitored, they are recorded in the appropriate registers, as well as the management and control over business activities are arranged. Tax accounting determines taxes and other compulsory payments, revenues, expenses and profits, formulates the tax base, calculates taxes, generates tax reports and pays taxes to the budget.

The annual increase in the amount of taxes and compulsory payments to the state budget, in a sense, necessitates keeping tax records.

Another theoretical foundation for accounting of tax liabilities is the Tax Code of the Republic of Uzbekistan. The Tax Code has a separate section called "Tax Reporting", which contains articles 76-84. Article 81 of the Tax Code of the Republic of Uzbekistan reveals the essence of the "tax reporting" concept. According to it "Taxpayer's documents, which include calculations and tax returns for each type of tax or income paid, as well as appendices to the accounts and tax returns, constitute a basis for determining the tax liabilities of taxpayers and tax agents" (Code, 2020). So, as long as the tax report is compiled, it is definitely done on the basis of financial and tax accounting data. Tax reports usually complement each other with financial statements. In particular, the total accrued and paid tax amounts in the financial statements are reflected in the tax returns by type of tax.

There various views of scholars on the "tax accounting" concept. For example, in the opinion of Z. Kurbonov, "Tax accounting is a system of collecting, recording, processing and summarizing information required for the accurate calculation of the tax base of taxes and compulsory payments by economic entities" (Kurbanov, 2006).
- Further, this scholar has provided even simplified definition of this concept: "Tax accounting is a system of accounting of primary data required to determine the tax base for taxes and compulsory payments of all individuals and legal entities operating independently" (Kurbanov, 2008).

Russian scientists V.Ya. Kojinov supposes, that "Tax accounting is a basic information system of financial and economic activity of the company, which is compiled in order to deduct a part of the income generated on the principles of accounting to the state budget"(Kojinovm, 2004).

From the point of view of N.A. Bretslavtseva with the reference to the Tax Code of the Russian Federation, "Tax accounting is a system of aggregating taxable base on the basis of data, generalized in reliance upon the primary document data" (Bretslavtseva, 2012).

Khotamov gives the proposal to make amendments to the invoice and invoice register lists with the account of transforming invoices into the register lists and tax reports with the aim of generalizing the data of the invoices and completing the invoice of any enterprise by the taxpayer ${ }^{1}$.

Based on the above considerations, the function of tax liability accounting is as follows:

- accurate calculation of the tax base and reflection in the primary documents in due time;

- $\quad$ accurate recording of advance tax payments in the relevant accounts; collecting, summarizing and reflecting of the tax information in the tax accounts;

- $\quad$ supervision over payment of taxes to the budget in due time;

http://www.indianjournals.com/ijor.aspx?target=ijor:i jmie $\&$ volume $=6 \&$ issue $=10 \&$ article $=001$ 
submission of tax reports according to the established procedure.

Comprehensive and systematic activities are being implemented in the field of accounting and audit, as in all areas, at the current stage of economic reforms ongoing in the Republic of Uzbekistan. Herewith, the central focus is made on the introduction of international financial reporting standards in the accounting practice of the republic. In particular, the Decree of the President of the Republic of Uzbekistan PD-4720 "On measures to introduce modern corporate governance in joint stock companies" dated April 24, 2015 has set the objectives to publish annual financial statements of all joint stock companies in compliance with International Auditing Standards and International Financial Reporting Standards in order to conduct an external audit.

In pursuance of this aim, on February 24, 2020, the President of the Republic of Uzbekistan adopted Resolution № PR-4611 "On additional measures to transfer to International Financial Reporting Standards" which has determined precise deadlines and mechanisms for transition to international financial reporting standards.

Definitely, currently the transition to international financial reporting standards is being carried out in reliance upon the government decisions and decrees. After all, as any country integrates into foreign markets, nowadays it is required to publish financial statements prepared on the basis of international financial reporting standards.

One of the most essential objectives of the transition to international financial reporting standards is integration into the international accounting system and complete provision of external accounting information of business entities, including investors, in due time. Therefore, the main issue is to obtain complete, reliable and quality information, both when conducting accounting on the basis of national standards and when it is formulated in reliance upon international financial reporting standards.

According to the Law of the Republic of Uzbekistan "On Accounting", accounting information is based on primary accounting documents, processed information about the objects of accounting, reflected in accounting registers, financial statements, explanatory notes and other documents related to the organization and maintenance of accounting. The objects of accounting are economic transactions related to assets, liabilities, equity, reserves, income, expenses, profits, losses and their flow.

From the statements specified above, it is obvious that liabilities are listed separately as the object of accounting in the legislation. The accuracy and completeness of the information about the liabilities not only makes the information easier to use, but also makes the conclusion more objective.

Ensuring accuracy of accounting information on liabilities, processing the information obtained by external users of the information will constitute the basis for reasoning and drawing conclusions.

In compliance with the current legislation, when accounting for tax liabilities, the chart of accounts provides for the opening of accounts as part of current liabilities. That is, tax debts to the budget are accounted for as part of current liabilities. The following table lists the sources of information on tax liabilities in the financial statements (Table 1).

\section{Table 1}




\section{Sources of information on tax liabilities reflected in the balance sheet ${ }^{2}$}

reflects the debts (by type) on payments to the budget. However, the current normative

\begin{tabular}{|c|l|}
\hline $\begin{array}{c}\text { Code } \\
\text { of line }\end{array}$ & \multicolumn{1}{c|}{ Indicator } \\
\hline 270 & Advance payments to the budget on taxes and other compulsory payments \\
\hline 540 & Long-term deferred liabilities for taxes and compulsory payments \\
\hline 650 & Deferred liabilities for taxes and compulsory payments \\
\hline 680 & Debts on payments to the budget (by type) \\
\hline
\end{tabular}

documents in the literary sources also

From the data in this table, it is obvious that some lines of the financial reporting forms provide information on taxes. In our opinion, tax amounts should be entirely disclosed in the financial reporting forms.

Another aspect is that in cases where tax liabilities are long-term (deferred or installment payment of taxes), the total (for several years) amount of estimated tax is calculated and reflected in the account 6410 "Debts on payments to the budget (by type)" and actually paid causes the difference between the sums. For example, the amount of tax accrued on long-term contracts, in which a company has calculated and paid all taxes payable in the current year, the amount of indebtedness due to the payment of taxes in installments arises artificially because all the calculations summarize the data of the account 6410 "Debts on payments to the budget (by type)".

In addition, the transfer of payments of some taxes to other liability accounts in the accounting of tax liabilities also complicates the accounting of tax liabilities and does not provide adequate information. The term "accounting of tax liabilities" implies the account 6400 - "Debt on payments to the budget" for practicing accountants, tax officials, auditors and other bookkeepers. In fact, the information in these accounts

${ }^{2}$ Source: Developed by the authors based on balance sheet data. complicate calculation of tax liabilities, which do not enable to analyze and control tax amounts through specific accounts.

In our opinion, in order to optimize the system of accounts used in practice and regulated by the national accounting standard, it is required to systematize them through accounts that reflect separate tax amounts (Table 2). 


\section{Table 2.}

Current accounts on which tax liabilities are maintained $^{3}$

\begin{tabular}{|l|l|c|}
\hline № & \multicolumn{1}{|c|}{ Essence of the account } & $\begin{array}{c}\text { By } \\
\text { National } \\
\text { Accounting } \\
\text { Standard } \\
21\end{array}$ \\
\hline 1. & Debts on payments to the budget (by type) & 6400 \\
\hline 2. & Excise and value added taxes calculated in the import process & 6900 \\
\hline 3. & Long-term deferred liabilities for taxes and other compulsory payments & 7240 \\
\hline 4. & Long-term liabilities for deferred income tax on temporary differences & 7250 \\
\hline 5. & $\begin{array}{l}\text { Write-off of targeted tax incentives due to the end of their availability period } \\
\text { or as a result of their use }\end{array}$ & 8530 \\
\hline 6. & Deferred liabilities for taxes and other compulsory payments-current part & 6240 \\
\hline 7. & $\begin{array}{l}\text { Long-term liabilities for deferred income tax on temporary differences- } \\
\text { current part }\end{array}$ & 6250 \\
\hline
\end{tabular}

\footnotetext{
${ }^{3}$ Source: compiled by the author.
} 
Currently taxes payable to the budget, are reflected in the accounts 6200 - "Accounts for overdue liabilities", 7200 - "Accounts for overdue long-term liabilities", 6900 "Accounts receivable for various creditors", 8530 - "Free property" and in other similar non-tax related accounts.

In reliance upon the statements specified above, in order to facilitate the transparency of data, accounting, tax liability accounting and reporting, to obtain information on tax liabilities: current tax arrears should be reflected in account 6400 - "Debts to the budget (by type)" and the long-term part should be reflected in account 7400 - "Debts to the budget (by type)" (Figure 1).

Accounting of taxes in this order results in the accumulation of tax amounts in accounts 6400 and 7400, thus simplifying calculation of liabilities and control activities. Nowadays only account 6410 - "Debts on payments to the budget (by type)" is used in practice in the structure of account 6400 . The rest of the tax debts (6990, 6240, 6250, 7240, 7250) are reflected in the accounts with a completely different essence. In general, accounts other than 6410 (6420-6490) should be used to determine sources of tax liability information. It should be noted that modifications should be made in the relevant lines of the financial statements in reliance upon these proposals.

We know that in the items of the balance sheet, each of the accounts 6990, 6240, $6250,6410,7240,7250$ is reflected in separate lines. The company calculates the total tax debt based on the balance sheet data by summarizing the data of several accounts for collection. It is impossible to determine the amount of tax in the account 6900- "Accounts payable to various lenders" because the amount of tax on this account, together with other accounts payable, is reflected in the balance sheet. 


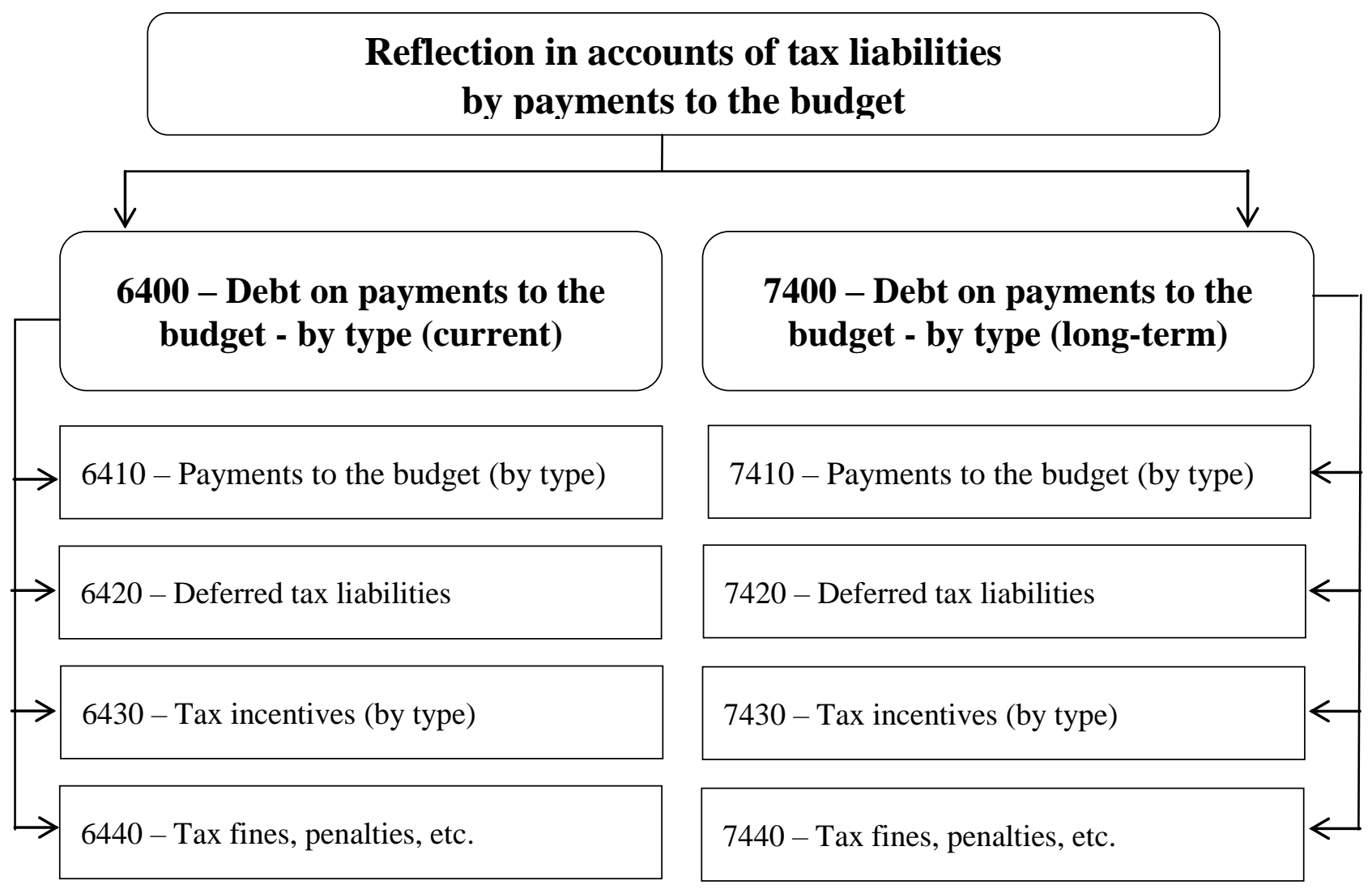

Figure 1. Reflection of debts on payments to the budget (by type) in the accounts ${ }^{4}$

${ }^{4}$ Source: compiled by the author. 
The structural change in the accounts which we are proposing and the application of the new proposed account will enable to summarize the information on the accounts, as well as bring the tax amounts into one system. This enables to conduct a comparative analysis of balance sheet data with tax returns, making it easier to keep track of tax liabilities. In addition, it will ensure transparency of information obtained on tax liabilities.

\section{CONCLUSION AND PROPOSALS}

The functions of the tax liability accounting are as follows:

- $\quad$ accurate calculation of the tax base and reflection in the primary documents in due time;

accurate recording of advance tax payments in the relevant accounts; collecting, summarizing and reflecting of the tax information in the tax accounts;

- $\quad$ supervision over payment of taxes to the budget in due time; submission of tax reports according to the established procedure.

Accounting of tax liabilities in accounts 6400 and 7400 simplifies the performance of accounting and control of tax liabilities, leading to the consolidation of tax amounts in two accounts.

In addition, it is required to make amendments in the relevant lines of the financial statements on the accounting of tax liabilities.

\section{REFERENCE}

1. Code (2020). Tax Code of the Republic of Uzbekistan: Tashkent, "Adolat", 2020, 400 p.
2. Decree (2015) Decree of the President of the Republic of Uzbekistan PD № 4720 “On measures to introduce modern corporate governance methods in joint stock companies" dated April 24, 2015.

3. Resolution (2020). Resolution of the President of the Republic of Uzbekistan PR № 4611 “On additional measures for transition to international financial reporting standards" dated February 24, 2020.

4. Order (2003). Order of the Ministry of Finance of the Republic of Uzbekistan "On approval of financial reporting forms and rules for their completion" (Registered by the Ministry of Justice of the Republic of Uzbekistan under № 1209 on January 24, 2003).

5. $\quad 5 . \quad$ Standard (2002). On approval of the National Accounting Standard of the Republic of Uzbekistan (NAS № 21) "Chart of accounts of financial and economic activities of economic entities and instructions for its application" (Registered by the Ministry of Justice of the Republic of Uzbekistan under № 1181 on October 23, 2002).

6. Isroilov B.I. (2006) Tax accounting and analysis: problems and their solutions. - T.: «Uzbekistan», 272 p.

7. Bretslavtseva N.A.(2012). Accounting.Educational aid.-Feniks, $318 \mathrm{p}$.

8. Kurbanov Z.N (2008). Methodological problems of tax accounting and auditing. Monograph.-T.:Fan va texnologiya, $156 \mathrm{p}$.

9. Kurbanov Z.N (2006). Tax accounting: Theory and methodology. -T.: «Fan» publishing house, $108 \mathrm{p}$. 
The American Journal of Social Science and Education Innovations (ISSN - 2689-100x)

Published: November 30, 2020 | Pages: 628-636

Doi: https://doi.org/10.37547/tajssei/Volumeo2Issue11-109

2020: $5 \cdot 525$

OCLC - 1121105668

10. Kojinov V.Ya (2004). Tax accounting.

KNORUS, $656 \mathrm{p}$.

Educational aid for accountant. - M.: 